\title{
Observations on reproductive features of three species of Eunicidae (Polychaeta) associated with Posidonia oceanica seagrass meadows in the Mediterranean Sea
}

\author{
M.C. GAMBI and M. CIGLIANO
}

Laboratorio di Ecologia del Benthos, Stazione Zoologica “Anton Dohrn”, Ischia, Naples, Italy. E-mail: gambimc@szn.it

\begin{abstract}
SUMMARY: Observations on the reproductive features are provided for three species of Eunicidae (Lysidice ninetta Audouin and Milne Edwards, Lysidice collaris Grube and Nematonereis unicornis (Grube)). They all occur in Posidonia oceanica meadows as borers in the sheaths. The material examined was collected during several studies on $P$. oceanica meadows conducted at various times of the year and in different years along the coasts of Sardinia and the Ischia islands (Tyrrhenian Sea), and Otranto (Southern Adriatic Sea). All individuals of the three species were measured (width $3^{\text {rd }}$ chaetiger, diameter of eyes), and checked for presence of gametes. In each of the females recognized, egg diameter was measured. To integrate the observations, living specimens were collected in March 2003 and reared in the laboratory until August 2003 to check for gamete maturation; mature males were fixed for analysis of the structure of the spermatozoa by transmission electron microscopy (TEM). All three species studied are gonochoric. For both species of Lysidice gametes occurred in individuals with a width greater than $0.8 \mathrm{~mm}$. The overall scarcity of mature males and females observed with respect to the total number of specimens collected is probably due to the dimensional constraint exerted by the sheaths. In Lysidice spp. specimens with small developing oocytes were observed in January-February and reached their maximum diameter between June and August $(157 \mu \mathrm{m})$. Gametes were located mainly in the posterior part of the body, and an enlargement of the eyes (almost doubled in size) characterized mature specimens close to spawning. N. unicornis is a smaller species, and it is less frequent in Posidonia sheaths than Lysidice spp.; individuals with gametes had a width greater than $0.55 \mathrm{~mm}$. A few mature specimens were observed between March and May with a maximum egg diameter of about $155 \mu \mathrm{m}$. In this species maturation of the gametes is coupled with a huge enlargement of the eyes (ten-times larger than in immature individuals), while the posterior part of the body is swollen and full of mature gametes, indicating reproduction by schizogamy. Analysis of mature spermatozoa of the three eunicids revealed a similar morphology, which is that of an "ectaquasperm" type, typical of many free-spawning species with external fertilization. The nucleus is round and globose (2.5 $\mu \mathrm{m}$ diameter) and the acrosome, slightly different among the three species, has the general shape of a truncate sub-cone.
\end{abstract}

Keywords: Polychaetes, Eunicidae, Lysidice, Nematonereis, reproductive biology, Posidonia oceanica, Mediterranean Sea.

RESUMEN: OBSERVACIONES SOBRE LAS CARACTERÍSTICAS REPRODUCTORAS DE TRES ESPECIES DE EUNICIDAE (POLYCHAETA) ASOCIADAS A PRADERAS DE la FANERóGAMa MARINA POSIDONIA OCEANICA EN El MAR MEDITERRÁNEO. - Se discuten algunas caracteristicas generales de la biología de la reproducción de tres especies de poliquetos Eunicidae (Lysidice ninetta Audouin and MilneEdwards, Lysidice collaris Grube y Nematonereis unicornis (Grube)). Estas especies fueron obtenidas en praderas de Posidonia oceánica, en donde viven asociadas a las escamas de las hojas. El material examinado fue recolectado en diferentes anos y en praderas de $P$. oceánica distribuidas en la costa de Cerdeña, de la isla de Ischia (Mar Tirreno), y de Otranto (Mar Adriatico Sur). Todos los individuos fueron medidos (anchura del tercer segmento, diámetro de los ojos), y analizados para observar en ellos la presencia de los gametos. En cada hembra se midió el diámetro de los huevos. El desarrollo de otros individuos fue observado en el laboratorio desde Marzo a Agosto 2003 con la finalidad de estudiar la maduración de los gametos. Los machos maduros fueron fijados para el análisis de la ultra-estructura de los espermatozoos al Microscopio Electrónico. Las tres especies estudiadas son gonocóricas (sexos separados). Para las dos especies del genero Lysidice las hembras con huevos siempre se presentaron en individuos superiores en anchura a $0,8 \mathrm{~mm}$. La escasez de hembras y machos maduros en relación al total de individuos está probablemente relacionado con las limitaciones que suponen las dimensiones y espesor de las escamas de Posidonia. Individuos de Lysidice spp. con huevos pequeños en desarrollo se observaron desde Enero-Febrero; los oocitos alcanzaron el máximo diámetro en Junio y Agosto $(157 \mu \mathrm{m})$. Los gametos se localizaron preferentemente en la parte posterior del cuerpo, y cuando los individuos alcanzaron la madurez, sus ojos se hicieron más anchos (casi el doble en su diámetro). N. unicornis es una especie más pequeña, y menos frecuente en las escamas de Posidonia que Lysidice spp. Los individuos con gametos presentan 
anchuras superiores a 0,55 mm. Algunos individuos maduros fue observado desde Marzo a Mayo, con diámetros máximos de los huevos de casi $155 \mu \mathrm{m}$. En esta especie la madurez se relaciona con un enorme aumento del diámetro de los ojos (diez veces mas anchos que en individuos inmaduros), y en la dilatación de la parte posterior del cuerpo llena de gametos maduros; esta característica indica una reprodución de tipo eschizogámico. La ultra-estructura de los espermatozoos maduros es muy similares en las tres especies de Eunicidae, de tipo"ect-aquasperm”, típicas des especies con fecundación externa. El núcleo (2,5 $\mu$ m en diámetro) es redondo y globular, y el acrosoma, que es un poco diferente entre las especies, es de forma general en cono truncado.

Palabras clave: poliquetos, Eunicidae, Lysidice, Nematonereis, biología de la reproducción, Posidonia oceanica, mar Mediterráneo.

\section{INTRODUCTION}

Polychaetes show a diversity of reproductive traits that is unique amongst Metazoa, and this is also confirmed by the numerous different pathways of oogenesis existing within the class (Giangrande, 1997). Eunicidae, as far as is known, are polytelic and gonochoric, without sexual dimorphism. Their reproductive habits, mainly studied for relatively few species of the genera Palola, Eunice and Marphysa, include free-spawning and brooding of the eggs, planktotrophic, lecitothophic, and direct development, as well as often schizogamy (epitoky) involving a modified posterior end full of gametes that is detached at maturity for spawning near the water surface (Wilson, 1991; Giangrande, 1997; Rouse and Pleijel, 2001).

Among the Eunicidae Lysidice ninetta Audouin and Milne Edwards, 1833, Lysidice collaris Grube, 1870 and Nematonereis unicornis (Grube, 1840) are species relatively common in different coastal habitats. Both species of Lysidice are cryptic forms already known as borers into calcareous algae and therefore commonly found in both shallow and deep coralligenous-dwelling assemblages (Martin, 1987; Cantone, 1993). L. ninetta, is a species largely distributed in warm and temperate waters (George and Hartmann-Schroeder, 1985; Cantone, 1993; Castriota et al., 2003). L. collaris is a pan-tropical species, considered a possible lessepsian migrant in the Mediterranean (Ben-Eliahu, 1972) and also reported in 1987 in the north-western Mediterranean (Martin, 1987). N. unicornis is a cosmopolitan species showing a wider ecological distribution, occurring also in soft bottom assemblages (George and Hartmann-Schroeder, 1985; Cantone, 1993). The three species represent also the few species that are able to bore into the seagrass Posidonia oceani$c a$, where they colonize the sheaths (remains of former leaf bases persisting along the rhizome) by boring complex galleries inside the scale mesophyll (Guidetti et al., 1997).

The occurrence and ecology of these species within the $P$. oceanica sheaths has been reported in several studies dealing with spatial distribution at different scales (Di Maida et al., 2003; Gambi et al., 2005 and references therein), temporal distribution (Gambi and Cafiero, 2001; Gambi, 2002) and trophic ecology (Gambi et al., 2000).

Relatively few and mainly anecdotal data are available on reproduction of these species. Lo Bianco (1909) reported the presence of mature females of $L$. ninetta in November in the Gulf of Naples. Fage and Legendre (1927) observed specimens with gametes in about $3 / 4$ of the posterior part of the body, and they asserted that in the Mediterranean Sea the spawning takes place between June and August. Gravier and Dantan (1928), observed many anterior and posterior fragments in night plankton collected in the Bay of Alger. Hofmann (1975), summarizing data of different authors on eunicid reproduction, indicated a period of sexual maturity between June and November, a pelagic larva and a pelagic way of reproduction, although the fate of spawned worms is unknown. George and Hartmann-Schroeder (1985) reported mature females in April in the northern Atlantic Ocean (Jersey). Murina $(1992,1997)$ working in the Black Sea reported the phenology and distribution of the pelagic larval stage, and defined the larvae of L. ninetta to be of type 1: "warm water, short distance, neritic epipelagic". Finally, Castriota et al. (2003) studying a population associated with an algal rhodolith bed off the island of Ustica (Southern Tyrrhenian Sea) from November 1996 to June 1998, found only 12 females larger than 0.8 mm width and with an egg diameter between 90 and $180 \mu \mathrm{m}$. According to this study reproduction seems to take place in summer, followed by a period of recruitment, probably indicated by the occurrence of the smallest individuals within the rhodolith beds in December (Castriota et al., 2003).

For L. collaris, there appears to be no available data on reproductive features in the literature, while for N. unicornis Fage and Legendre (1927) collected mature specimens at night in the plankton in May and June in the Atlantic Ocean (Concarneau) and in the Mediterranean Sea (Banyuls). They observed 
gametes in the posterior part of the body (from the $62^{\text {nd }}$ chaetiger to the end of the body), confirming similar observations first made by Claparède (1864).

\section{MATERIAL AND METHODS}

Specimens of the three species studied were obtained from $P$. oceanica shoots collected during different research programmes. Most of the material came from temporal studies performed on borers of P. oceanica beds around the island of Ischia (Gulf of Naples, Thyrrenian Sea) (Gambi, 2002 and references therein), and at Otranto (Southern Adriatic Sea) (Gambi et al., 2003). Other material was collected during a large regional survey along the coast of Sardinia in summer 2001 (Gambi et al., 2005).

To evaluate the population structure (size-frequency pattern), the width of all specimens was measuredat the $3^{\text {rd }}$ chaetiger (a variable well-correlated with dry weight biomass, M.C. Gambi, unpublished data). Total length was also measured in entire specimens initially, but later abandoned since many individual were incomplete at the rear end. The diameter of the eyes was measured in specimens bearing gametes and in a sub-set of individuals not bearing gametes in order to check morphological changes related to maturation and reproduction. In all recognisable females the egg size was measured by checking the diameter of about 50-60 eggs per specimen. Measurements were made using a microscope fitted with a micrometer ocular. One-way ANOVA, and the NewmanKeuls test were performed to test differences in mean egg-size at the different times of collection.

Supplementary observations were made by collection of some living specimens between March and June 2003 in P. oceanica meadows off the island of Ischia. Individuals of each species were maintained inside the sheath and were reared in sea water in Petri dishes under controlled temperature conditions $\left(18^{\circ} \mathrm{C}\right)$ until August of that year. Twice a week the specimens were checked under a stereomicroscope to monitor gamete development. Three mature males of each species were fixed in $2.5 \%$ glutaraldehyde for later observation using a transmission electron microscope (Philips 400 TEM). After fixation the samples were washed in buffer for $1 \mathrm{~h}$ and then post-fixed with $1 \%$ osmium tetroxide in the same buffer for $1 \mathrm{~h}$. All fixation steps were performed at $4^{\circ} \mathrm{C}$. Fixed specimens were dehydrated through graded concentrations of ethanol (20 min for each alcohol concentration) followed by propylene oxide (10 min) and a mixture of epoxy resin and propylene oxide (1:1 for $5 \mathrm{~h}$ in a drier), and embedded in epoxy resin $\left(2\right.$ days at $\left.60^{\circ} \mathrm{C}\right)$. Silvergrey sections were stained with alcoholic uranyl acetate followed by lead citrate.

\section{RESULTS}

All three species studied are gonochoric, and at maturity both female and male specimens were easily distinguished by gamete type, although no sexual dimorphism was present. The gametes were free in the coelom and concentrated in the posterior region of the body. The eggs of mature females were bright pink in colour, while mature males had a milky appearance.

As a general rule, at Otranto (southern Adriatic Sea), very few ovigerous females were recorded from any of the three species studied (Table 1).

\section{Lysidice ninetta}

In all 1151 specimens of L. ninetta were gathered at the various study sites. Due to the fact that

TABLE 1. - Number of ovigerous females of the three eunicid species recorded in different locations and months. Only the months where ovigerous specimens were found are reported.

\begin{tabular}{|c|c|c|c|c|c|c|c|c|c|c|c|}
\hline Ischia island & Jan. & Feb. & Mar. & Apr. & May & Jun. & Jul. & Aug. & Sep. & Oct. & Dec. \\
\hline Lysidice collaris & - & 1 & 1 & 1 & 14 & 1 & 7 & 3 & 4 & 1 & 1 \\
\hline Lysidice ninetta & 2 & 1 & 3 & 2 & 9 & 1 & 7 & 1 & - & 1 & - \\
\hline Nematonereis unicornis & - & 1 & 3 & - & 3 & - & - & - & - & - & - \\
\hline Sardinia coast & Jun. & Jul. & Aug. & \multicolumn{4}{|c|}{ Otranto } & Feb. & May & & \\
\hline Lysidice collaris & 13 & 5 & 4 & \multirow{3}{*}{\multicolumn{4}{|c|}{$\begin{array}{l}\text { Lysidice collaris } \\
\text { Lysidice ninetta } \\
\text { Nematonereis unicornis }\end{array}$}} & - & - & & \\
\hline Lysidice ninetta & 10 & 1 & - & & & & & 1 & 1 & & \\
\hline Nematonereis unicornis & 3 & - & - & & & & & 1 & - & & \\
\hline
\end{tabular}



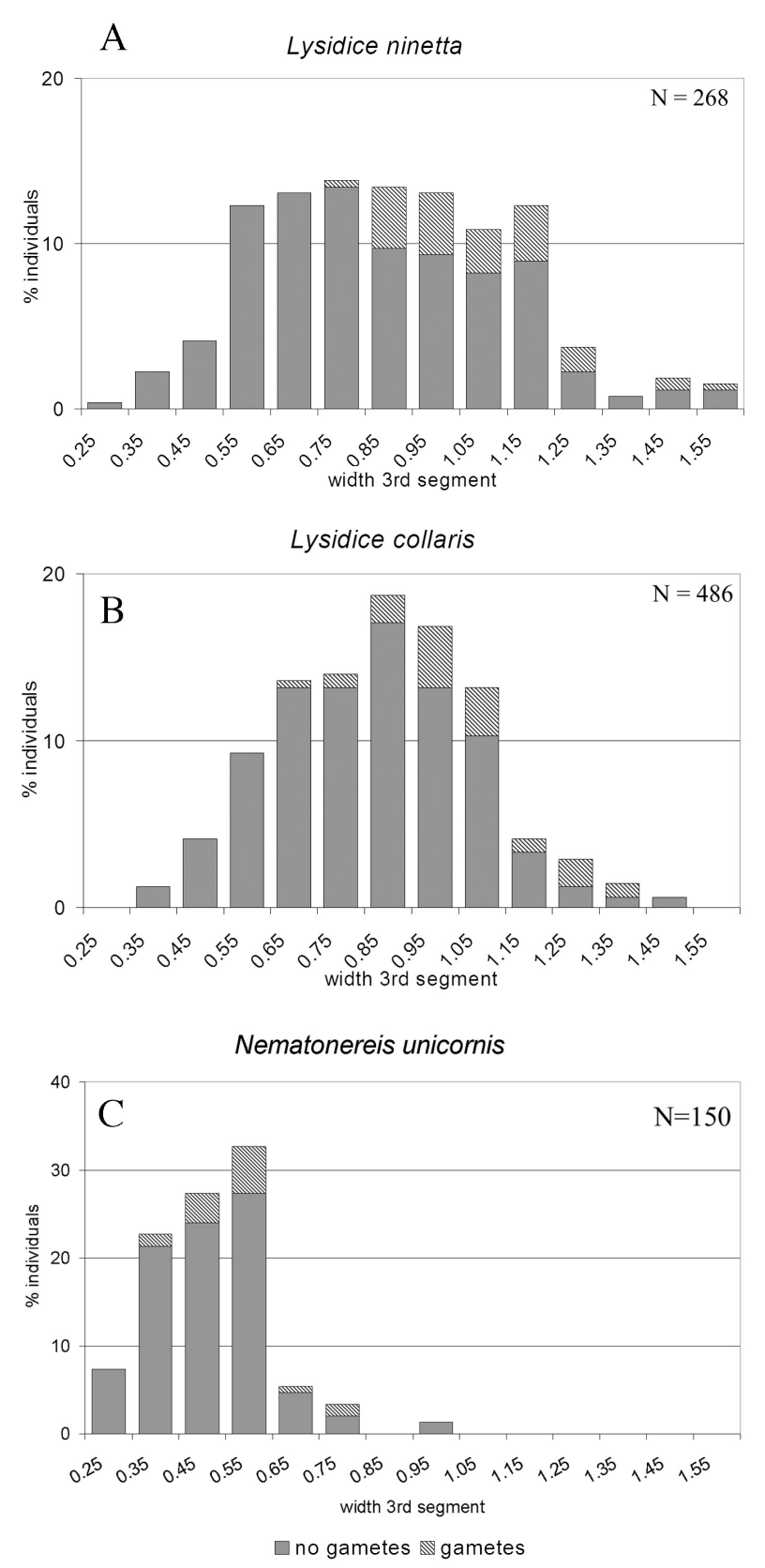

FIG. 1. - Size/frequency distribution of A, Lysidice ninetta; B, Lysidice collaris; C, Nematonereis unicornis specimens. Striped histograms show specimens with gametes.

in each site, regardless of period of collection, specimens were relatively few, their numbers did not allow an estimate of the size/frequency pattern for different months and locations. Instead a size/frequency histogram was constructed for all complete specimens collected in order to present a picture of the size spectrum of the species and the minimum size of ovigerous females. The size of all specimens collected ranged from 0.3 to $1.5 \mathrm{~mm}$ width, and with a total length between 17 and 62 $\mathrm{mm}$. Both small (width $<0.45 \mathrm{~mm}$ ) and large
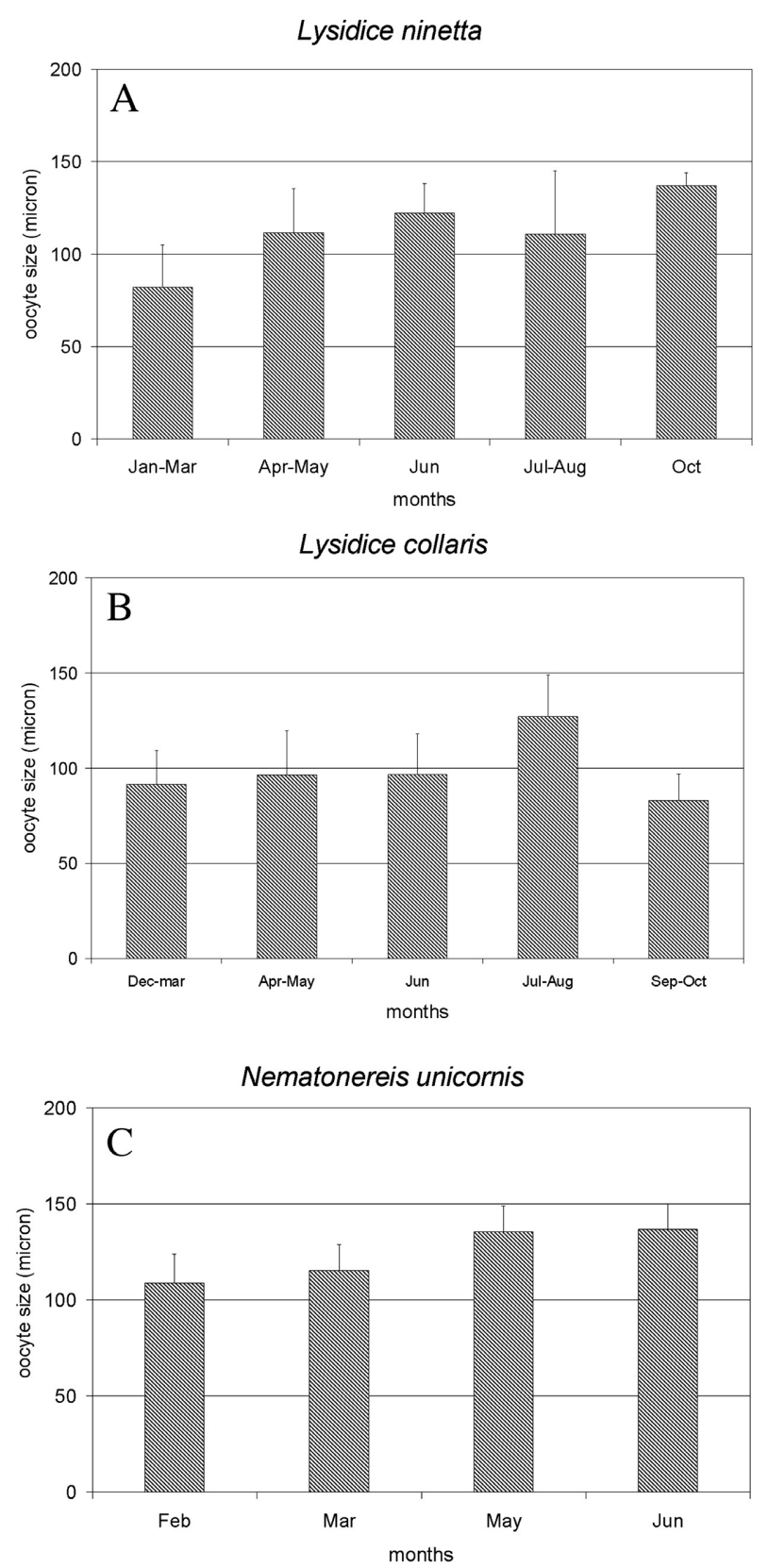

FIG. 2. - Trend of the mean oocyte size A, Lysidice ninetta, B, Lysidice collaris and C, Nematonereis unicornis in various months. Bars represent standard deviations.

(width $>1 \mathrm{~mm}$ ) specimens were scarce. 44 specimens $(3.8 \%$ of all individuals) were bearing gametes, and 40 were females (Table 1) They showed a body size ranging from $0.7 \mathrm{~mm}$ to $1.5 \mathrm{~mm}$ width, and were more frequent in large sizes (Fig. 1A). In the females the oocytes were first recognizable between January and March (Table 1), and the mean oocyte size showed an increase from May to October (Fig. 2A).

The egg-size distribution showed a progressive increase of egg-size classes from March to 

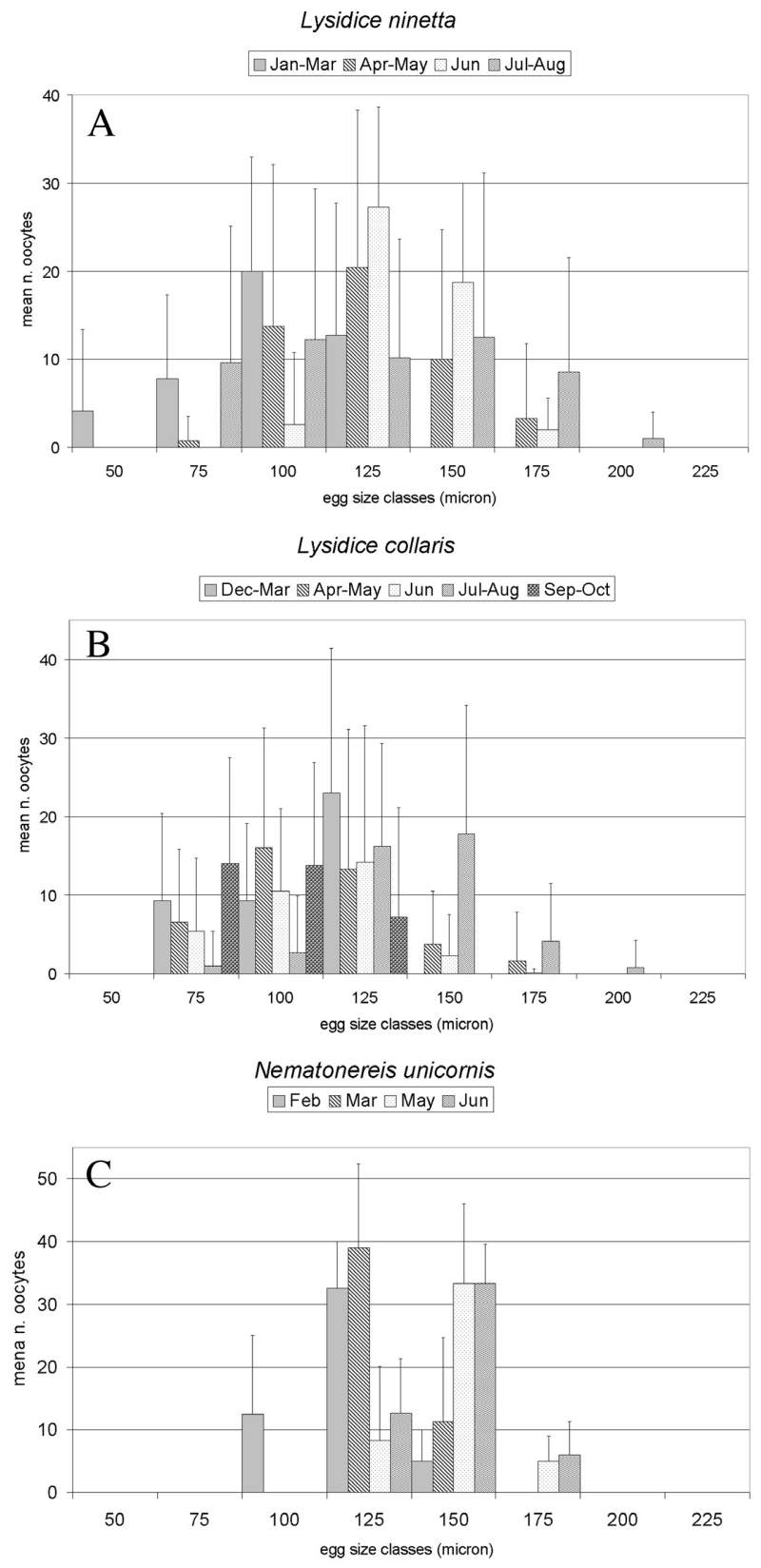

FIG. 3. - Distribution of egg-size classes in A, Lysidice ninetta, B, Lysidice collaris, C, Nematonereis unicornis specimens in different sampling periods.

October, indicating a quite discrete oocyte development. The ANOVA analysis of egg size showed statistical differences in all months $(\mathrm{F}=38.94, \mathrm{p}<$ 0.01 ), except between April and May, and between June and July (Newman-Keuls test). The most frequent egg-size classes were between 125 and 150 $\mu \mathrm{m}$ (Fig. 3A). Although at Ischia and along the coast of Sardinia, ovigerous females were found in similar periods (June, July), their very low number did not allow testing of the correlation of egg size and reproduction.
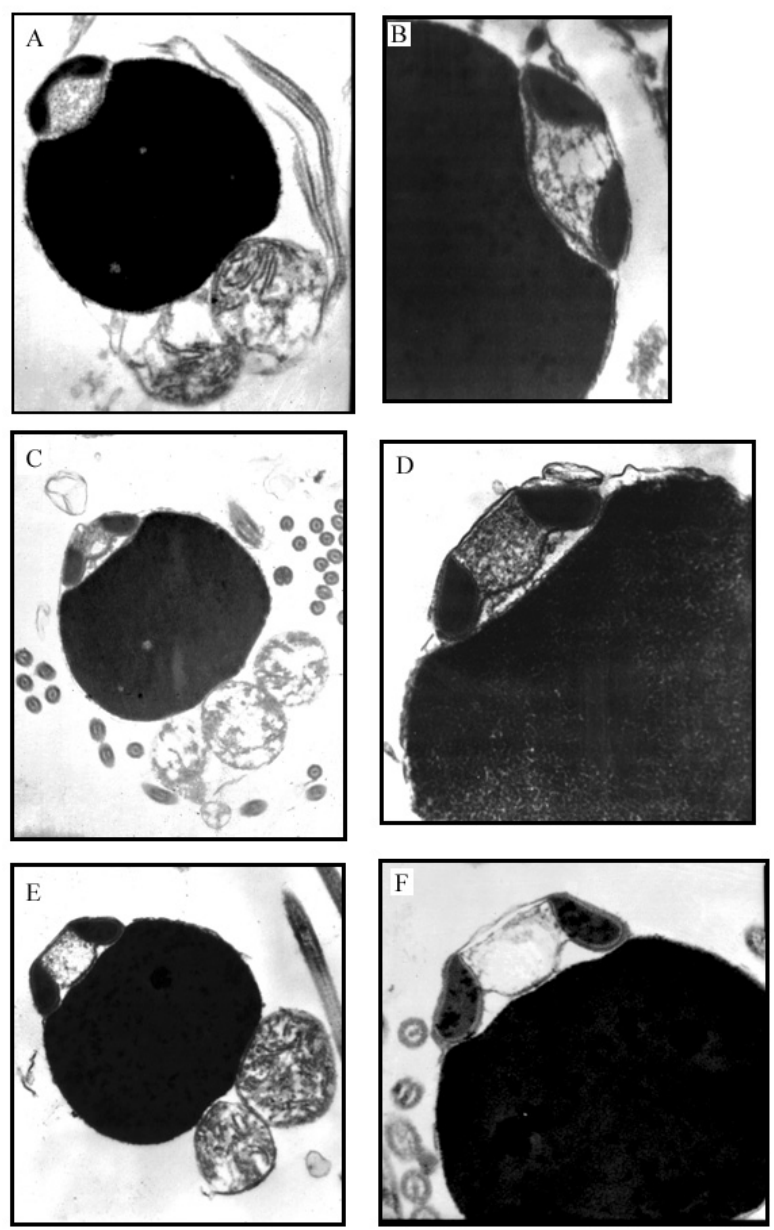

FIG. 4. - TEM micrographs of mature spermatozoa of A, Lysidice ninetta entire sperm (22000X); B, detail of the acrosome (36000X); $\mathrm{C}$, Lysidice collaris entire sperm (17000X); D, detail of the acrosome (36000X); E, Nematonereis unicornis entire sperm (17000X); $\mathrm{F}$, detail of the acrosome (22000X). In all pictures the diameter of the sperm nuclei is $2.5 \mu \mathrm{m}$

The mature spermatozoa of $L$. ninetta are characterized by a sub-spherical nucleus $(2-2.5 \mu \mathrm{m}$ in diameter) with highly condensed chromatin, a small number (two or three) of rounded, cristate mitochondria and a free flagellum (Fig. 4A). The acrosome is a truncated and relatively flat sub-cone, and consists of a membrane-bounded acrosomal central vesicle, and two oval lenses on the side of the cone constituted by the sub-acrosomal substance (Fig. 4B). According to Jamieson and Rouse (1989) this overall sperm morphology is an "ect-aquasperm" type.

In mature specimens a doubling of eye size was observed (Fig. 6A).

\section{Lysidice collaris}

In all 1631 specimens of $L$. collaris were collected. As for L. ninetta the relatively low number of 

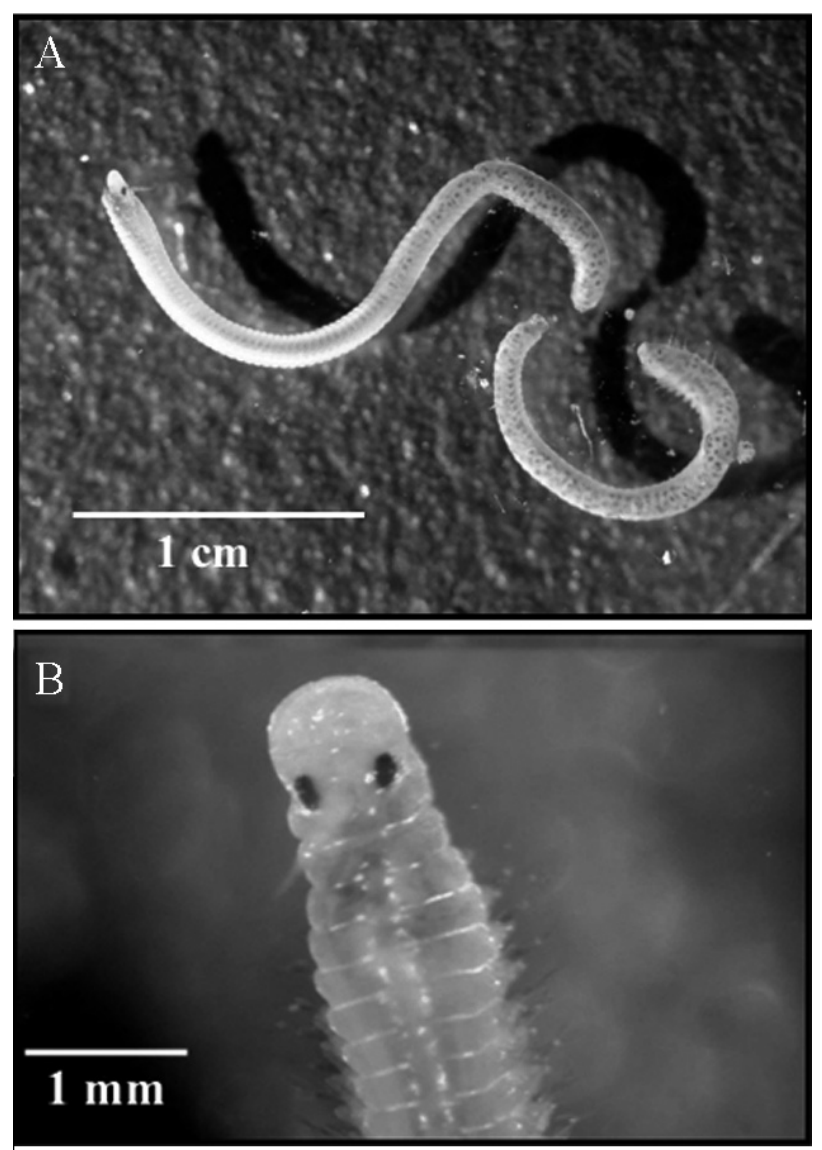

FIG. 5. - A, mature female of Nematonereis unicornis with the posterior body (partially detached) full of eggs; B, dorsal view of the prostomium of a mature female of $N$. unicornis with enlarged eyes.

specimens collected each month in each of the study locations, did not allow estimation of the temporal pattern of the population structure. Thus a size/frequency histogram was constructed for all specimens collected. The size of specimens ranged from 0.3 to $1.5 \mathrm{~mm}$ in width, and had a total length between 20 and $61 \mathrm{~mm}$. Even for this species low numbers of small (width $<0.45 \mathrm{~mm}$ ) and large (width $>1 \mathrm{~mm}$ ) individuals were observed. Sixty-two specimens (3.8\% of all individuals) of a size ranging from 0.6 $\mathrm{mm}$ to $1.0 \mathrm{~mm}$ width had gametes (Fig. 1B). In the 56 females observed in various periods (Table 1) the mean oocyte diameter was quite constant from December to June and showed a slight increase in July-August (Fig. 2B). The ANOVA analysis of egg size showed statistical differences in egg size between the periods July-August and SeptemberOctober and all the other periods (Newman-Keuls test). The egg size showed a relatively wide range in the various periods, suggesting a prolonged oocyte development; the most frequent egg-size classes ranged from 85 to $125 \mu \mathrm{m}$ (Fig. 3B). Although at
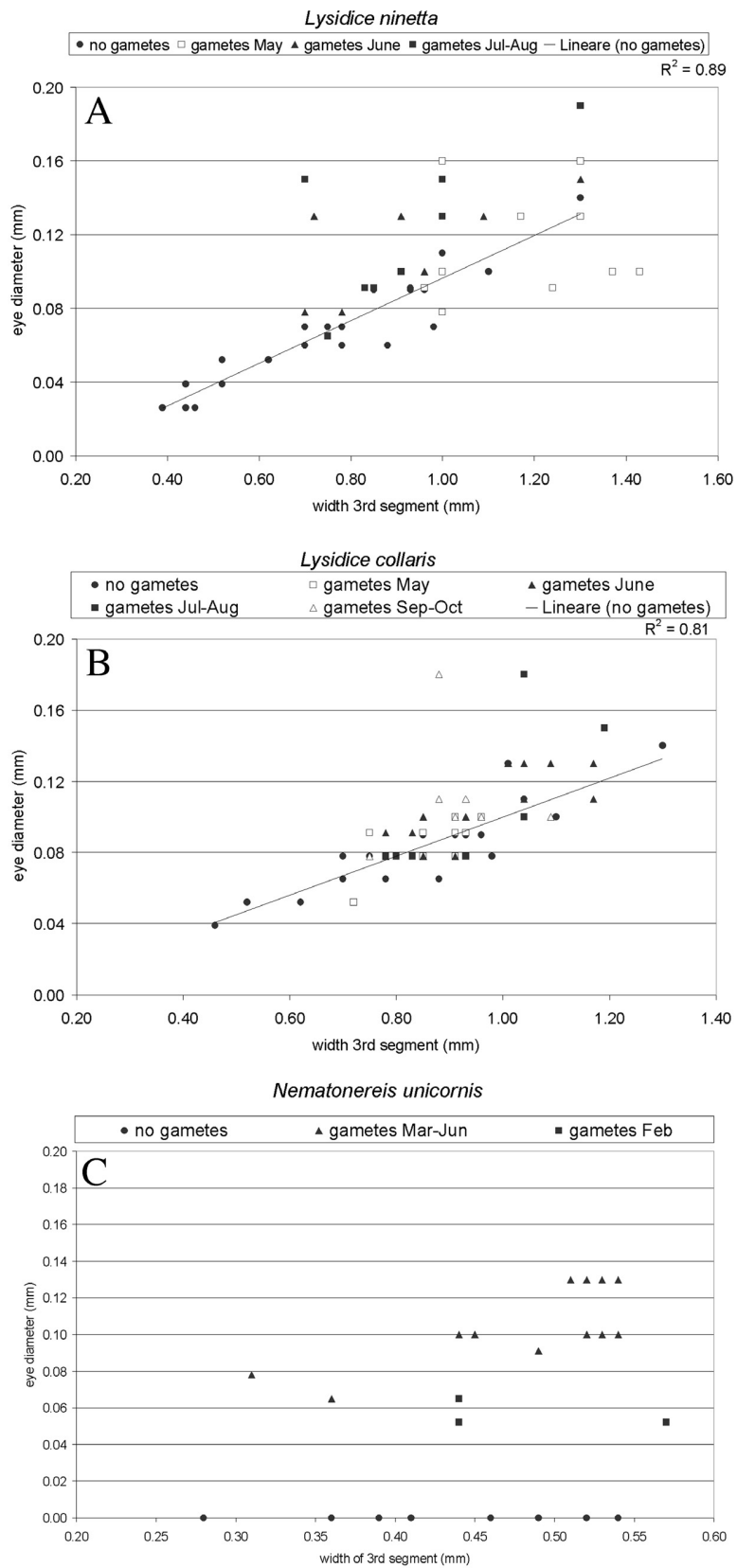

FIG. 6. - Eye diameter of A, Lysidice ninetta, B, Lysidice collaris and $\mathrm{C}$, Nematonereis unicornis immature and mature specimens in various months and according to size. The lines in Lysidice spp. represent the linear regressions of eye diameter and $3^{\text {rd }}$ chaetiger width in immature specimens; note that the eye dimension of most mature specimens lies above those lines.

Ischia and along the coast of Sardinia ovigerous females of $L$. collaris were found in similar periods (June, July and August), their very limited number did not allow testing of the correlation between egg size and reproduction.

The morphology of the mature spermatozoa of $L$. collaris is very similar to that of L. ninetta ("ectaquasperm" type), with a rounded nucleus and an almost identical acrosomal structure (Fig. 4C and D). 
Also in mature L. collaris specimens the eyes doubled in diameter at maturity (Fig. 6B).

\section{Nematonereis unicornis}

A total of 397 N. unicornis specimens were gathered. Also for this species the relatively low number of specimens collected in different months and locations favoured pooling of all the specimens into a single size-frequency histogram. The size of individuals collected ranged from a width of 0.25 to $0.85 \mathrm{~mm}$, a width range smaller and more limited than that for the two Lysidice species; while the total length ranged between 15 and $50 \mathrm{~mm}$. The population structure showed few specimens larger than $0.6 \mathrm{~mm}$ width (Fig. 1C). Fourteen specimens (3.5\% of all individuals) had gametes. In the 11 females observed (Table 1) egg diameter ranged between 109 and $137 \mu \mathrm{m}$ and, despite their limited numbers, showed a clear increase in egg size between February and June (Fig. 2C). The ANOVA analysis of egg size showed statistical differences between the periods February-March and May and June $(\mathrm{F}=104.53, \mathrm{p}<0.01)($ Newman-Keuls test). The egg-size distribution suggests a synchronous and discrete oocyte development (Fig. 3C). The mature spermatozoa had an overall morphology very close to that of the two Lysidice species ("ectaquasperm" type) (Fig. 4E and F). However, the acrosome in $N$. unicornis seemed to have a slightly larger internal vesicle than in the Lysidice species.

In the most mature specimens the posterior region of the body was full of gametes and swollen, and was so delicate that in some of the living specimens observed it detached during manipulation (Fig. 5). This morphology suggests detachment of the posterior region at spawning (schizogamy). In mature specimens near to spawning the eyes increased to a diameter ten times greater than that in immature worms (Figs. 5 and 6C).

\section{DISCUSSION}

The three species of eunicids borers of $P$. oceani$c a$ sheaths showed some common characteristics and some differences in their life and reproductive features. The two Lysidice species exhibited a similar size range, with both small and large individuals relatively scarce. Juveniles may be prevented from entering the Posidonia sheaths by mechanical constraints since the tissue of the sheath is quite tough.
Thus Lysidice spp. specimens may colonize the sheath only after reaching a size when their feeding apparatus is probably strong enough to attack the sheath tissues. Larger specimens, on the other hand, are constrained by the size of the sheaths, in particular by the sheath's thickness. Maximum sheath thickness in Posidonia scales is around $1.3 \mathrm{~mm}$, the same value as the maximum width of the largest worms collected in the sheaths. However, mean sheath thickness is much lower (around 0.5-0.6 mm), therefore the majority of specimens should fit this size or be smaller. For both species of Lysidice individuals with eggs had a width larger than $0.7 \mathrm{~mm}$, indicating a size threshold for gamete development in these species. Thus the relatively few mature specimens found could be due again to size constraint exerted by sheaths. A similar size constraint and minimum size for mature specimens was observed in the population of $L$. ninetta associated with calcareous rhodoliths studied in the Tyrrhenian Sea (Castriota et al., 2003).

In $L$. ninetta reproduction seems to take place in summer, thus confirming the previously available data, as well as the record of larvae and adult fragments in the plankton (Hofmann, 1973; Murina, 1992, 1997). For this species oocyte development seemed to be a relatively discrete event, with a maturation period from July to October.

For L. collaris the reproductive period, as well as oocyte development, was more prolonged than for $L$. ninetta suggesting a semi-continuous reproduction, although with a peak in summer. This difference in timing of reproduction and oocyte development is probably due to the fact that L. ninetta is a warm-temperate species and $L$. collaris is a tropical species. In both species maturation is coupled with a doubling of the eye size.

Although the body width range recorded for N. unicornis is more limited than in Lysidice spp., an abrupt reduction of specimens larger than $0.6 \mathrm{~mm}$ width was evident and is unlikely to be related solely to size constraint due to sheath dimensions, as in Lysidice spp.. This pattern is most likely related to swarming of larger specimens outside the sheath for spawning of the gametes. Indication of the possible occurrence of schizogamy is supported by the extremely swollen posterior region full of gametes in mature specimens.

The egg mean dimension and egg/size frequency distribution indicate that oocyte development is possibly a synchronous event, with reproduction taking place between March and June, earlier than in the two Lysidice species. 
Morphological changes in N. unicornis also involve an enormous increase of the eye size, another character often observed in association with schizogamy and epitoky. Thus we can suppose that reproduction takes place with swarming of specimens in the water column and releasing of posterior regions. The previous observation by Fage and Legendre (1927) on swarming of mature individuals of this species at night in the plankton is consistent with this pattern, and the rare occurrence of individuals larger than $0.6 \mathrm{~mm}$ could be due to this reproductive behaviour.

The three species studied also showed comparable maximum egg size at maturity (around $175 \mu \mathrm{m}$ ); this size suggests planktotrophic development of the larvae. The few available data for other Eunicidae, mainly belonging to the genera Palola, Eunice and Marphysa, confirm that egg fate and development (planktotrophic vs lecitothorophic) depends on egg size (Giangrande, 1997).

Finally, the three taxa showed a very similar sperm morphology, corresponding to the ectaquasperm type. Jamieson and Rouse (1989) asserted that the ect-aquasperm type is a spermatozoon which is liberated freely into the ambient water in which it (potentially at least) fertilizes a similarly free egg. The observed sperm morphology, coupled with the probably occurrence of schizogamy, support the premise that all the studied species are free spawners with external egg fertilization.

Our observations demonstrated that, although the habitat in which the three eunicid species were studied (the $P$. oceanica sheaths) exerts a strong size constraint, it was possible to define their main reproductive features and their general life cycle pattern.

\section{AKNOWLEDGEMENTS}

We wish to thank Gennaro Piro for measuring some of the worms. The T.E.M. preparations and micrographs were made by the Microscopy Service of the Stazione Zoologica “A. Dohrn” of Naples.

\section{REFERENCES}

Ben-Eliahu, M.N. - 1972. Littoral Polychaeta from Cyprus. Tethys, 4(1): 85-94.

Cantone, G. - 1993. Censimento dei policheti dei mari italiani: Eunicidae Berthold, 1827. Atti Soc. Tosc. Sci. Nat. Mem Serie B, 100: 229-243.
Castriota, S., M.C. Gambi, V. Zupo and G. Sunseri. - 2003. Structure and trophic ecology of a population of Lysidice ninetta (Polychaeta) associated to rhodoliths off the island of Ustica (Southern Tyrrhenian Sea). Biol. Mar. Medit., 10(2): 517-520.

Claparède, E. - 1864. Glanures zootomiques parmi les Annèlides de Port-Vendres (Pyrénées Orientales). H. Georg, Libraire Genève 572-578.

Di Maida, G., M. Pirrotta, P. Calì, F. Cascino, A. Tomasello and S. Calvo. - 2003. Distribuzione dei borers nelle praterie di Posidonia oceanica della Sicilia. In: R. Casagrandi and P. Melià (eds.), Proceedings XIII ${ }^{\circ}$ SItE Congress. pp. 10-16. Aracne, Roma.

Fage, L. and R. Legendre - 1927. Pêche planctonique à la lumière effectuée à Banyuls-sur-Mer et à Concarneau: I Annélides Polychètes. Arch. Zool. Exp. Gen., 67: 23-222.

Gambi, M.C. - 2002. Spatio-temporal distribution and ecological role of polychaete borers of Posidonia oceanica (L.) Delile scales. Bull. Mar. Sci., 71(3): 1323-1331.

Gambi, M.C. and G. Cafiero. - 2001. Functional diversity in the Posidonia oceanica ecosystem: an example with polychaete borers of the scales. In: F.M. Faranda, L. Guglielmo and G., Spezie (eds.), Mediterranean ecosystems: structures and processes. pp. 399-405. Springer-Verlag.

Gambi, M.C., V.Zupo and M. Lorenti-2000. Borer organisms of the Posidonia oceanica scales: trophic role and ecological implications for the ecosystem. Biol. Mar. Medit., 7(1): 253-261.

Gambi, M.C., M. Lorenti and M. Cigliano. - 2003. Un nuovo gruppo di consumatori di detrito nel sistema Posidonia oceanica del Mediterraneo: gli organismi perforatori delle scaglie (policheti e isopodi). Biol. Ital., 3: 28-35.

Gambi, M.C., B. Trani and M.C. Buia. - 2005. Taxonomic diversity and distribution of polychaete and isopod borers on the sheaths of the seagrass Posidonia oceanica: analysis at regional scale along the coast off Sardinia (Italy). Ital. J. Zool., 72: 141-151.

George, J.D. and G. Hartmann-Schroeder. - 1985. Polychaetes: British Amphinomida, Spintherida and Eunicida. In: D.M. Kermack and R.S.K. Barnes (eds.), Synopses of the British Fauna (New Series), 32: 1-221.

Giangrande, A. - 1997. Polychaete reproductive patterns, life cycles and life histories: an overview. Ocean. Mar. Biol. Ann. Rev., 35: 323-386.

Gravier, C. and J.L. Dantan. - 1928. Pêche nocturnes à la lumière dans la Baie d'Alger. Ann. Inst. océanogr., Paris, n.s., 5: 147-150.

Guidetti, P., S. Bussotti, M.C. Gambi and M. Lorenti. - 1997. Invertebrate borers in Posidonia oceanica scales: relationship between their distribution and lepidochronological parameters. Aquat. Bot., 58: 151-164.

Hofmann, D.K. - 1975. Reproductive forms in Eunicid Polychaetes inhabiting the "fonds coralligènes" in the region of Banyuls-surMer (Mediterranean Sea) with particular reference to Eunice siciliensis Grube. Pubbl. Staz. Zool. Napoli, 39: 242-253.

Jamieson, B.G.M. and G.W. Rouse. - 1989. The spermatozoa of the Polychaeta (Annelida): an ultrastructural review. Biol. Rev., 64: 93-157.

Lo Bianco, S. - 1909. Notizie biologiche riguardanti specialmente il periodo di maturità sessuale degli animali del Golfo di Napoli. Mittheilung. Zool. Stat. Neapel, 19(4): 576- 589.

Martin, D. - 1987. Anélidos poliquetos asociados a las concreciones de algas calcareas del litoral catalàn. Misc. Zool., 11: 61-75.

Murina, V.-1992. Phenology of pelagic larvae of Polychaeta in the adjacent of the Mytilus farm off the southern coast of Crimea. In: Polychaeta and their ecological significance. Explorations of the Fauna of the Seas, 43(51): 152-157. (In Russian with English abstract)

Murina, V. - 1997. Pelagic larvae of Black Sea polychaeta. Bull. Mar. Sci., 60(2): 427-432.

Rouse, G. and F. Pleijel. - 2001. Eunicidae Berthold, 1827. In: G.W. Rouse and F. Pleijel (eds.), Polychaetes, pp. 155-157. Oxford University Press, New York.

Wilson, W.H. - 1991. Sexual reproductive modes in polychaetes: classification and diversity. Bull. Mar. Sci., 48: 500-516.

Received September 15, 2004. Accepted May 11, 2005. 